\title{
Estimating Demolition Costs for Single Residential Buildings
}

Chunlu Liu (Senior Lecturer, School of Architecture and Building, Deakin University, Australia), Benjamin Lyle (Undergraduate student, School of Architecture and Building, Deakin University, Australia) and Craig Langston (Professor, School of Architecture and Building, Deakin University, Australia)

\section{ABSTRACT}

With the increasing stock of aging structures, building demolition is becoming a challenging research field from the perspective of management. As the converse of construction, management of demolition puts forward some new management themes or adds some new contents even though the same issues are faced in construction management. This research aims to develop a quantitative approach to estimate the costs of a demolition project. A cost analysis method is presented to systematically break down the cost components involved in the demolition of a structure. Due to the lack of robust research in theory and systematic summary in practice to date, the economic performances of demolition will be studied through a case study, and the majority of parameters are derived from actual experiences in practice. The proposed demolition cost estimation method is applied to the actual form of building elimination (Scenario 1), and further comparison is carried out with two other elimination methods, which are the newly developed deconstruction (Scenario 2) and mechanical demolition (Scenario 3). Deconstruction is found to be the most profitable in this particular instance, and is closely followed by the actual form.

Keywords: demolition cost, deconstruction, residential buildings, salvaged materials, waste minimisation.

\section{INTRODUCTION}

The lifecycle of a building or infrastructure project has widely been recognised as comprising five stages: planning, design, construction, maintenance, and demolition. A lifecycle approach has also been considered to play an important role in project management by integrating these five stages simultaneously in the pre-construction microeconomic assessment of individual projects although the demolition stage was rarely given full consideration. Since the 1980s maintenance has been given more attention, and it attracted further emphasis in the 1990s as reviewed in Itoh and Liu (2000). Choate and Walter (1981) argued that there was an infrastructure crisis in the USA due to inadequate maintenance of existing facilities. This became clear when a number of bridges in the USA subsequently collapsed partially or completely (Dunker and Rabbat, 1993). The lessons learned from these failures and disasters led to better understanding of the importance of proper maintenance. Harding et al. (1996) concluded that, at least until the mid 1990s, most national governments and local authorities throughout the developed world had switched their minds from new infrastructure projects to the maintenance of the existing stocks.
The increased emphasis on maintenance and the wider realm of demolition is predominantly due to environmental pressures, particularly issues of waste disposal. Australians generate on average about one tonne of solid waste per person per year, which goes to landfill (Australian Bureau of Statistics, 2003). Construction and demolition of buildings contributes thirty to forty per cent of this waste. Accurate data for the division of construction and demolition waste have been unavailable from the waste disposal records in landfill due to the structure of landfill levies. In addition, construction waste and demolition waste are not distinguished in construction enterprises because demolition of a structure is generally followed by new development. Because construction waste materials are likely to be new and segregated, they are normally collected for recycling rather than sent straight to landfill. Conversely, the indiscriminate demolition of building structures produces enormous amounts of mixed materials that result in significant waste streams to landfill. In recent years there have been various attempts to improve landfill disposal technologies as well as to set up advanced recycling technologies (Chini, 2002). As further improvements in processing are technically limited, future efforts will have to concentrate on improving demolition itself (Liu et al., 2003). Research into developing environmentally friendly demolition technologies and management methodologies may provide the essential solution to release landfill pressure so as to inhibit the further degradation of environmental resources. Greater recycling of used materials through careful construction disassembly will contribute significantly to lower resource usage in new facilities and ultimately higher national prosperity (Langston and Ding, 2001).

Over several decades, techniques have been well developed to analyse and estimate the construction costs of buildings (Ostwald, 2001; Smith, 1998). The cost parameters of demolition, the reversed process of construction, have not been formulated (Abdullah et al., 2003; Lassandro, 2003). This paper reports research aimed at developing a quantitative approach for estimating the costs of a demolition project. It uses residential buildings as a case study type in order to take advantage of the number of single demolition occurrences and similar structural characteristics of this building type. This enables the collection of data from previous demolition projects and the tracking of new demolition projects. The actual demolition implementation performed on site is numbered as demolition strategy Scenario 1. The demolition strategy Scenario 2 is deconstruction, by which a building is 
dismantled in terms of its valuable structural components. Mechanical demolition, Scenario 3, involves the direct use of mechanical plant such as cranes, load-shifting equipment, and the like to completely demolish a building. This paper first describes the current situation of practical demolition, and then estimates demolition costs by breaking down major cost components. Other potential demolition scenarios are estimated and compared. It should be noted that the cost estimates are based upon the demolition of a single detached residential building, which comprises a single storey timber framed structure with weatherboard external cladding and sheet metal roof. No extrapolation of the data should be made for other types of houses, or for multidwelling demolition under a single contract.

\section{STATE OF THE ART OF PRACTICAL DEMOLITION}

The survey samples are concentrated in the Geelong region, Australia. Telephone communications and personal interviews were undertaken as part of the research method. Interviews were taped to fully document the information. Numerous site visits were pursued to record the key stages of demolition. Contact with the relevant parties also helped to enable sourcing of additional information relating to cost formulation parameters. The demographics of the interviewees ranged from large-scale demolition companies who only dabbled in residential building to small sub-contractors. The following general opinions on demolition were generated from the industry feedback, and are summarised according to demolition sector, demolition regulations, demolition projects, demolition technology, and salvaged material economics and market perspectives:

Demolition Sector: The demolition sector is highly fragmented like the construction industry generally. In the Geelong region, there are more than fifteen demolition contractors, which range from small companies that specialise in residential work to large businesses that primarily deal with commercial and industrial projects. In relation to this study, demolition contractors revealed that demolishing residential dwellings accounted from five to ninety-five per cent of their work.

Demolition Regulations: Various demolition regulations have been documented by government departments and professional authorities such as Standards Australia (2001) and Victorian WorkCover Authority (1998). In the Geelong region, the demolition work procedure includes a demolition permit granted by a municipal building surveyor. The demolition techniques must be documented in detail in the work procedure. For example, it is written in the demolition work procedure of the following case study that 'all materials including roof materials, windows, doors etc. are removed manually'; and 'no wall, chimney or other structure shall be left unattended or unsupported in such a condition that it may collapse due to wind or vibration or otherwise become dangerous'.
Demolition Projects: Generally, residential projects completed by industry respondents took on average between two and four days. These typically included removal of hazardous materials, strip-out if relevant, bulldozing or 'crunching' the site, and then clean.

Demolition Technology: Reasons given for why a company could not operate purely using a deconstruction approach were that wages and work cover premiums are too high, professional indemnity is an increasing problem, and deconstruction is perceived as a higher risk. An example of deconstructing a portal-framed gymnasium by an interview respondent indeed shows that deconstruction does exist in the right circumstances. Relocation of housing is acknowledged as a better alternative option to demolition, however social attitudes today do not always support the additional repairs and work necessary. It comes down to the view that there is currently a booming economy, and people are willing to pay for convenience and speed.

Salvaged Materials: Contractors when asked of their motivation to salvage materials generally replied that it had to be monetary motivation, with comments such as 'justified', or a 'struggle between good business and ethics' being used. This enforces the obvious focus of industry, where contractors have to make a profit. Furthermore, all opinions point in the same direction that the contractors have to want to be a recycler to succeed in setting up a salvage business. Popular items of salvage included Oregon timber beams, bricks, hardwood timbers, Baltic Pine timber flooring boards and older items that are popular for their antique value. Other pertinent knowledge gained was that older timber will not shrink and possesses a lot more character than new, but is harder on tools and must be successfully de-nailed. Used bricks do not shrink and would be ideal for rendered walls, and used carpet underlay can be re-used as weed mats for landscaping. There is thus a 'fashion' culture operating in materials salvage activity, alongside a more practical 'alternative use' approach.

Salvaged Material Market: The salvaged materials market is currently struggling due to a secure economic climate, where the average home handyman will source new material from a hardware store rather than even considering second-hand materials. The general consensus is that education would be required to change this behaviour.

\section{COMPONENT IDENTIFICATIONS OF DEMOLITION COSTS}

A general demolition cost analysis method is especially required while appraising the economic performance of a new demolition technique or introducing a new policy or regulation. Due to the lack of previous research on demolition cost components, cost parameters are drawn from typical demolition projects detailed from investigations. A cost analysis method is developed with consultation from 
various participants to deal with environmentally preferred cost effective solutions and disposal of demolition waste. These participants include commercial companies as well government departments.

The demolition cost $(C)$ of a project comprises labour costs $\left(C_{j}\right)$, material costs (benefits from salvaged materials) $\left(B_{m}\right)$, plant costs $\left(C_{p}\right)$, environmental compliance costs $\left(C_{e}\right)$, and administrative costs $\left(C_{a}\right)$, as presented in Eq. 1:

$C=C_{i}-B_{m}+C_{p}+C_{e}+C_{a}$

Factors such as overtime and various other compulsory employee benefits must be accounted as a part of $\mathrm{C}_{i}$.

$B_{m}$ is the material costs, which in fact represents the income breakdown made from scrapping all recyclable materials and the resale of second hand materials. It is anticipated that contractors undertaking deconstruction projects will gain a greater overall return for the time and money outlaid compared to other methods, and that in an ideal situation, the benefits will eventually negate most if not all of the previous costs mentioned. It should be emphasised that the income calculated is only potential as materials are unsold at the moment of demolition.

The plant costs associated with a demolition project, $C_{p}$, include transport costs and the hire of trucks or bins to be picked up. These amounts directly depend on how efficient the demolition team is in terms of stacking and sorting and more importantly how much materials can be salvaged. Salvaged materials that are to be recycled or reused will also incur transport costs. The size of the job and company will determine the amount of each type of plant required, and thus cost. Plant may have to be hired if the work is beyond the normal scope of the company. The plant costs incorporate maintenance, storage, transportation, fuel and depreciation costs for companies that own their own equipment.

The cost element, $\mathrm{C}_{\mathrm{e}}$, encapsulates environmental compliance costs to the sub-contractor, including correct disposal of waste, dust protection, litter management on site, and water management.

Finally, $C_{a}$ is the administrative costs that are needed to run the subcontracting company. Items such as estimating, permits, equipment and maintenance have to be included when determining a cost breakdown for a demolition project.

DEMOLITION PROJECT FOR CASE STUDY

\section{Project Description for Case Study}

A residential building located in Queenscliff, near the Geelong city in Australia, was selected for the case study. The contractor is a local firm who mainly undertakes demolition of residential buildings. The researchers participated in the demolition planning and procedure. The residential building is a single storey, weatherboard-clad conventional timber-framed structure on stumps, comprising corrugated steel sheeting to the roof. The detached house measures approximately seventeen by fifteen metres in area $\left(255 \mathrm{~m}^{2}\right)$ on a forty by fifty metre block of land, which is surrounded by a number of established trees. According to the development permits approved by the local council, any of the matured trees on the site should not be disturbed and little or no change should be apparent in the appearance of the new building compared to the existing one. This results in a constraint on the demolition contractor's working environment.

The demolition project was conducted over four days. Before commencing work on site there is a typical process starting with a request forwarded to the contractor to submit a quote. Once the quote is accepted, authorisation is given to do the work. Services disconnection is organised by the builder, hazardous material notifications are submitted to relevant authorities, and work cover compliance documentation is sighted. A brief description of the four-day procedure undertaken by the demolition contractor is as follows:

Day 1: Services are disconnected on arrival, and the front fence is taken down to enable truck access. Four labourers on site assess the practical salvage ability of materials and strip-out flooring boards, weatherboard cladding, and window frames, and remove sheeting from the roof. One labourer is also a truck driver who delivers salvaged material back to the yard periodically. Only one company truck is used for this purpose, and the crew work for eight hours.

Day 2: Four labourers are on site working for eight hours. Much the same activity occurs as on the previous day, with the removal of architraves, timber wall and ceiling linings. Selected battens and rafters from roof and decking are also extracted from the dwelling. One company truck with a driver is again used all day, constantly transporting salvaged material back to the yard.

Day 3: Final strip out of remaining materials for salvage occurs. One labourer and one truck driver work on site for approximately half a day, concluding with a site clean-up process of any scattered debris.

Day 4: Beginning immediately, the mechanical arm of a twenty-three tonne excavator pulverises the corner of the main timber frame of the house, and the hired excavator operated by the company foreman works for approximately nine hours to fully knock down the dwelling, and load it into two alternating trucks, transporting the rubbish to the Drysdale tip. A few loads are transported to the demolition yard to be sorted for firewood. One truck is hired, and the company truck operates with the driver also assisting the operator in salvaging items from the demolished structure, such as large Oregon timber beams and fascia, which ends 
up back at the yard, along with corrugated sheet from the roof which was stockpiled on site.

\section{Cost Summary of Actual Demolition (Scenario 1)}

The demolition strategy Scenario 1 is based on the data gained from the demolition site. The cost summary aims to be as accurate as possible, whilst allowing for the fact that the aim of this method is to get valuable elements out for re-sale. All cost components that are categorised in Eq. 1 must be calculated separately to break down the costs incurred by the contractor. The detailed items of labour costs, salvaged material benefits, plant costs, environmental costs, and administrative costs are listed in Appendixes 1, 2, 3,4 , and 5 respectively. These separate calculation methods will also be applied to the alternative demolition strategies. Assumed monetary return allows for the salvaged material to be transported to a selling yard, where it has been stacked, cut, de-nailed or marked as required to re-sell.

\section{COST ESTIMATION OF ALTERNATIVE DEMOLITION SCENARIOS}

\section{Deconstruction and Mechanical Demolition}

Two other demolition strategies for the case study dwelling are identified according to the potential of salvaging demolition materials: the deconstruction (Scenario 2) and mechanical demolition (Scenario 3). Cost components in these scenarios are calculated and compared using the actual site data, further investigations and assumptions where necessary. In some cases an actual cost may not exist and therefore an assumption is made for an hourly rate for the purposes of this cost comparison. This measure is used in an endeavour to document every factor that may have an influence on the overall benefits of each demolition strategy.

Deconstruction is an idealised demolition method from the perspective of perfecting demolition material reuse and recycling, by which the building is dismantled in terms of its valuable construction elements. Costs developed for deconstruction are modelled on the parameters of the case study site, aiming to depict what costs would be involved if a medium-sized subcontract company specialising in deconstruction completed the project. The deconstruction method assumes that more time and care is taken to remove the building components. It can be assumed that roughly fifty per cent of degraded timber is salvaged for firewood to be sold. Pertinent items that have been allowed for, contrary to the case study, in costing the project include: the building is completely disassembled by hand without mechanical use; more estimating and tool use costs are incurred; more time is taken to complete, and therefore more labour costs; one more truck is needed to transport materials during the strip out phase; nearly all timber not salvaged in lengths is cut for firewood; and wastage is generally calculated at twenty-five per cent (sourced from the real case). The amount of materials that could possibly be salvaged from site is closely related to the extra hours allowed.

Using the mechanical demolition strategy, it is assumed that a few demolition materials are salvaged for reuse. It is roughly assumed that the subcontractor gains ten per cent of the average income of the previous two formulations for the purpose of this exercise. It is also assumed that one excavator owned by the company is used for crunching the house in one day. Four trucks delivering approximately five loads each to landfill will be required, as well as a small mechanical excavator and two trucks the following day for a final site clean. The contractor in this case is assumed to travel further to site than the local company that actually completed the work. The total demolition cost in Scenario 3 is representative of the amount that this company would reasonably salvage on this project, by doing a quick sweep before running a machine through the dwelling. These items may be sold immediately, taken back to their yard or scrapped at a recycling depot.

\section{Cost Comparisons of Three Demolition Strategies}

Similar to the cost breakdown procedure above carried out for Scenario 1 in Appendices 1-5, the detailed items of labour costs, salvaged material benefits, plant costs, environmental costs, and administrative costs can be calculated for both Scenarios 2 and 3. Close calculation aiming to depict each economic component is on the basis of specific characteristics incorporated in deconstruction or mechanical demolition in collaboration with experienced demolition contractors (Lyle, 2003). By adding the cost factors together, Table 1 depicts the three building elimination methods and their relevant costs estimated for the whole project and per square metre. The eventual profit gained by the deconstruction method (Scenario 2) is slightly higher than the actually applied method (Scenario 1) providing that all materials salvaged are sold. Scenario 3 appears to be more expensive for the contractor according to these cost estimations. This table clearly shows that the two 'salvage based' methods of taking the building down and disposing of its elements perform the best financially.

The total summaries of costs do not account for which demolition strategy achieves a better initial profit, and the immediate costs should also be compared. The cost estimations assume that salvage income in the long term can be subtracted from the project costs in order to give an overall net cost of demolition. It may, however, be years before the financial rewards from the sale of all of the salvaged materials are realised. If the income variables are taken out of the equation, another comparison, as shown in Figure 1, is undertaken to identify how much each method of building demolition actually costs the subcontractor at the time of completion. These costs are arguably close to what it would cost the contractor to complete the works. It can 
be seen that the medium level salvage option based on the actual implementation (Scenario 1) leaves the contractor in the best financial position once the project is finished on site. It should be noticed that this situation may change with the development of better demolition-related technology, better management, more regulation, and fluctuating market issues, such as the increased conservation of forests resulting in timber becoming scarcer, and increased tipping fees discouraging the removal of rubbish to landfill.

\section{CONCLUSIONS AND DISCUSSION}

In this research, a quantitative approach has been undertaken to formulate the cost of a demolition project in detail. The developed cost analysis method was applied to compare the costs of a practical demolition project under the real demolition scenario with two other alternative demolition strategies. It can be noticed from the cost comparisons that the labour costs are the highest cost components in both Scenarios 1 and 2 whilst the mechanical demolition method clearly shows that its environmental costs cannot be justified.

A number of positive parameters and attitudes towards accomplishing deconstruction are required, which could come in the form of a government subsidy, or an overwhelming increase in the second hand material market. It can be seen that over time deconstruction can be viable, particularly if its labour intensity is reduced. This would require further study into techniques and dismantling systems. Part of such research should also address the issues of designing buildings for subsequent disassembly. The second hand market of salvaged demolition materials can also stimulate deconstruction implementation through a positive profit situation. As deconstruction provides a potential solution to the problem of reducing waste entering landfill, it may also be enforced indirectly through a drastic increase in tipping fees at landfill sites.

\section{ACKNOWLEDGEMENTS}

The writers would like to thank the anonymous referees for their insightful suggestions and helpful corrections on an earlier draft of the paper.

\section{REFERENCES}

Abdullah, A., Anumba, C., and Durmisevic, E. (2003). Decision Tools for Demolition Techniques Selection. Proceedings of the 11th Rinker International Conference on Deconstruction and Materials Reuse, Gainesville, 55-72.

Australian Bureau of Statistics (2003). Year Book Australia, Number 85, Canberra.

Chini, A.R. (2002). Design for Deconstruction and Materials Reuse, CIB Publication 272. International Council for Research and Innovation in Building Construction, Miami.
Choate, P. and Walter, S. (1981). America in Ruins: Beyond the Public Works Port Barrel. Council of State Planning Agencies, Washington.

Dunker, K. and Rabbat, B. (1993). Why America's Bridges are Crumbling? Scientific American, 268(3), 18-24.

Harding, J, Parke, G., and Ryall, M. (1996). Preface. In Harding, Parke, and Ryall (Eds.), Bridge Management 3, E. \&FN SPON, London.

Itoh, Y. and Liu, C. (2000). Lifecycle Management Approach for Network-level Transportation Infrastructure Systems Based on Information Technologies. In Li, H., Shen, Q., Scott, D., and Love, P. (Eds.), INCITE 2000: Implementing IT to Obtain a Competitive Advantage in the 21st Century, Hong Kong, 300-314.

Langston, C. and Ding, G. (2001). Sustainable Practices in the built Environment (Second Edition), ButterworthHeinemann, London.

Lassandro, P. (2003). Deconstruction Case Study in Southern Italy: Economic and Environmental Assessment. Proceedings of the 11th Rinker International Conference on Deconstruction and Materials Reuse, Gainesville, 115-124.

Liu, C., Pun, S., and Itoh, Y. (2003). Technical Development for Deconstruction Management. Proceedings of the 11th Rinker International Conference on Deconstruction and Materials Reuse, Gainesville, 186-203.

Lyle, B. (2003). The Benefits of Deconstruction in the Construction Industry. Research Project Report, School of Architecture and Building, Deakin University, Geelong.

Ostwald, P. (2001). Construction Cost Analysis and Estimating, Prentice Hall, New Jersey.

Smith, J. (1998). Building Cost Planning for the Design Team, Deakin University Press, Geelong.

Standards Australia (2001). AS 2601-2001: The Demolition of Structures, Sydney.

Victorian WorkCover Authority (1998). Code of Practice (No. 21) - Demolition - Amendment, Melbourne. 


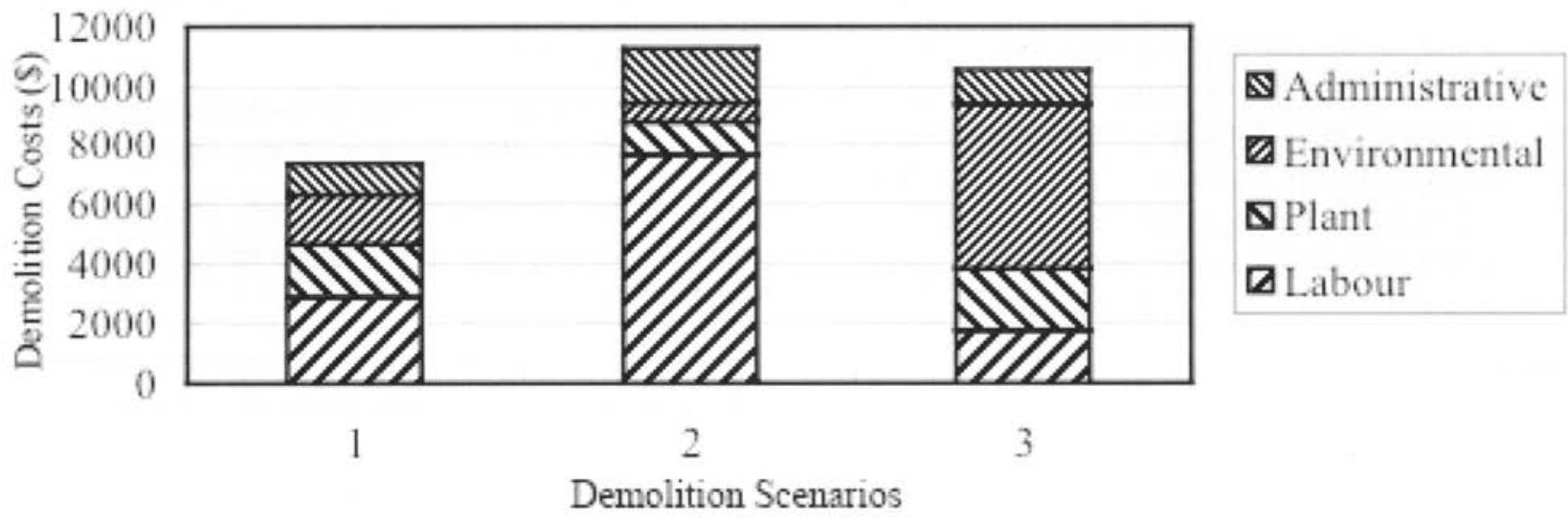

Figure 1: Comparison of immediate Project Costs in Three Demolition Scenarios

\begin{tabular}{|l|l|l|l|l|l|l|}
\hline \multirow{2}{*}{ Cost Items } & \multicolumn{2}{|l|}{$\begin{array}{l}\text { Scenario 2 (Deconstruction) } \\
\text { Scenario 1 } \\
\text { (Actual Implementation) }\end{array}$} & \multicolumn{2}{l|}{$\begin{array}{l}\text { Scenario 3 } \\
\text { (Mechanical Demolition) }\end{array}$} \\
\cline { 2 - 8 } & $\begin{array}{l}\text { for whole } \\
\text { project }\end{array}$ & per m2 & $\begin{array}{l}\text { for whole } \\
\text { project }\end{array}$ & per m2 & $\begin{array}{l}\text { for whole } \\
\text { project }\end{array}$ & per m2 \\
\hline Labour Costs (\$) & 2915 & 11.4 & 7680 & 30.1 & 1760 & 6.9 \\
\hline Material Benefits (\$) & -11509 & -45.1 & -15434 & -60.5 & -1347 & -5.3 \\
\hline Plant Costs (\$) & 1775 & 7.0 & 1129 & 4.4 & 2089 & 8.2 \\
\hline Environmental Costs (\$) & 1647 & 6.5 & 643 & 2.5 & 5554 & 21.8 \\
\hline Administration Costs (\$) & 1058 & 4.1 & 1822 & 7.1 & 1169 & 4.6 \\
\hline Total Cost (\$) & -4114 & -16.1 & -4160 & -16.3 & 9225 & 36.2 \\
\hline
\end{tabular}

Table 1: Comparison of Cost Parameters Depicting Three Demolition Scenarios 


\begin{tabular}{|c|c|c|c|}
\hline COST ITEMS & DESCRIPTION & COST REASONING & $\$$ \\
\hline Strip out, Day 1 & $\begin{array}{l}\text { Four Labourers, including one truck driver, } \\
\text { strip out material for salvage. Includes sorting, } \\
\text { stockpiling and loading materials for transport. }\end{array}$ & $\begin{array}{l}4 \text { labourers }{ }^{\star} 8 \text { hours each } \\
\text { Rate: approximately } \$ 30 / \mathrm{h}(\$ 22-\$ 23 / \mathrm{h}+\operatorname{tax} \text {, } \\
\text { superannuation, work cover premium, etc. })\end{array}$ & 960 \\
\hline Strip out, Day 2 & $\begin{array}{l}\text { Three Labourers strip out material for salvage } \\
\text { plus one truck driver to constantly take } \\
\text { materials back to yard. }\end{array}$ & $\begin{array}{l}3 \text { labourers*8 hours each } \\
1 \text { Truck driver*8 hours } \\
\text { Rate: Labourers ( } \$ 30 / \mathrm{h} \text { as above), driver } \\
\text { (approximately } \$ 25 / \mathrm{h} \text { as no demolition). }\end{array}$ & 920 \\
\hline Final strip out, Day 3 & $\begin{array}{l}\text { Final building elements are removed from } \\
\text { dwelling and transported from site. }\end{array}$ & $\begin{array}{l}1 \text { labourer }{ }^{\star} 5 \text { hours } \\
1 \text { Truck Driver }{ }^{*} 6 \text { hours } \\
\text { Rate: As above }\end{array}$ & 300 \\
\hline $\begin{array}{l}\text { Structure 'crunch' } \\
\text { and site clean, Day } 4\end{array}$ & $\begin{array}{l}\text { Excavator and } 2 \text { trucks work to crunch } \\
\text { dwelling and transport crushed materials } \\
\text { to yard and landfill. Materials of value are } \\
\text { salvaged. }\end{array}$ & $\begin{array}{l}1 \text { excavator operator, same rate as labourer } \\
\text { assumable. } \\
1 \text { company truck driver } \\
\text { Assume } 9 \text { hours taken to complete. }\end{array}$ & 495 \\
\hline $\begin{array}{l}\text { Salvaged materials } \\
\text { sorting }\end{array}$ & $\begin{array}{l}\text { One labourer works in yard to sort salvaged } \\
\text { materials like de-nailing, cutting timber for } \\
\text { firewood, etc. }\end{array}$ & $\begin{array}{l}\text { Estimated average } 12 \text { hours work. } \\
\text { Rate: Approximately } \$ 20 / \mathrm{h} \text { (less than demolition due } \\
\text { to less risk). }\end{array}$ & 240 \\
\hline & & Total Labour Costs & 2,915 \\
\hline
\end{tabular}




\begin{tabular}{|c|c|c|c|}
\hline COST ITEMS & DESCRIPTION & COST REASONING & $\$$ \\
\hline Weatherboards & $\begin{array}{l}\text { Cedar square-edged weatherboards used as } \\
\text { exterior cladding. }\end{array}$ & $\begin{array}{l}\text { Salvaged quantity: } 64 \mathrm{~m} 2 \text { (total removed: } 115 \mathrm{~m} 2 \text {, less } \\
45 \% \text { to allow for windows, poor quality areas and } \\
\text { small lengths) } \\
\text { Selling price: } \$ 6.40 / \mathrm{m} 2\end{array}$ & 410 \\
\hline Flooring & $\begin{array}{l}19 \mathrm{~mm} \text { Baltic Pine used throughout house, } \\
100 \% \text { removed. }\end{array}$ & $\begin{array}{l}\text { Salvaged quantity: } 141 \mathrm{~m} 2 \text { (total removed } 217 \mathrm{~m} 2 \text {, less } \\
45 \% \text { for poor quality areas and small lengths) } \\
\text { Selling price: } \$ 60 / \mathrm{m} 2\end{array}$ & 7,140 \\
\hline Architrave & $65 \mathrm{~mm}$ Meranti. & $\begin{array}{l}83 \mathrm{~m} \text { : (total removed } 150 \mathrm{~m}, 45 \% \text { unusable) } \\
\text { Selling price: } \$ 1 / \mathrm{m}\end{array}$ & 83 \\
\hline Lining boards & $\begin{array}{l}2 \text { rooms contained pine lining boards on walls } \\
\text { and ceiling. }\end{array}$ & $\begin{array}{l}42 \mathrm{~m} 2 \text { (total removed } 76 \mathrm{~m} 2 \text {, less } 45 \% \text { for doorways, } \\
\text { damaged or small pieces) } \\
\text { Selling price: } \$ 9.00 / \mathrm{m} 2\end{array}$ & 378 \\
\hline Window Frames & $\begin{array}{l}\text { Ranging from } 600 * 1000 \mathrm{~mm} \text { to } 1800^{*} 1800 \mathrm{~mm} \text {, } \\
\text { including glass. Roughly } 50 \% \text { are reusable. }\end{array}$ & $\begin{array}{l}\text { Can be sold for: } \\
4 \text { @ \$90ea }(600 * 1000) \\
5 @ \$ 120 \text { ea }(1000 * 1200) \\
3 @ \$ 175 \text { ea }(1800 * 1800)\end{array}$ & 743 \\
\hline Doors & $\begin{array}{l}\text { All doors made from solid core timber (four } \\
\text { panel). }\end{array}$ & $\begin{array}{l}11 \text { (total removed } 16,5 \text { for wastage) } \\
\text { Selling prices: maximum } \$ 150 \text { per door, average of } \\
\$ 70 \text { for them. }\end{array}$ & 770 \\
\hline Sub -floor & $\begin{array}{l}100 * 45 \text { Hardwood joists, not suitable for re- } \\
\text { use. }\end{array}$ & $\begin{array}{l}\text { Approximately } 1.5 \text { tonnes available, of which } 60 \% \text { was } \\
\text { made to yard. } \\
\text { Selling price: } \$ 40 \text { per trailer-load ( } \$ 3 \text { /tonne). }\end{array}$ & 108 \\
\hline Fascia & $\begin{array}{l}150^{*} 25 \mathrm{~mm} \text { Oregon fascia from perimeter of } \\
\text { house. }\end{array}$ & $\begin{array}{l}24 \mathrm{~m} \text { (total removed } 48 \mathrm{~m}, 50 \% \text { wastage) } \\
\text { Selling price: } \$ 4.40 / \mathrm{m}\end{array}$ & 106 \\
\hline Decking & $\begin{array}{l}70 * 19 \mathrm{~mm} \text { Jarrah decking from rear of house, } \\
\text { greyed but in reasonable condition throughout. }\end{array}$ & $\begin{array}{l}26 \mathrm{~m} 2 \text { (total removed } 40 \mathrm{~m} 2,35 \% \text { wastage). } \\
\text { Selling price: } \$ 14 / \mathrm{m} 2\end{array}$ & 364 \\
\hline GPO's & Twenty-seven GPO's available from dwelling. & $\begin{array}{l}\text { Possibly salvage } 45 \% \text { of GPO's available }=12 \\
\text { Sell second hand for } \$ 5 \text { each }\end{array}$ & 60 \\
\hline Copper & Small amount of copper salvaged. & $\begin{array}{l}\text { Approximately } 10 \mathrm{~kg} \text { of copper was salvaged @ \$2.40 } \\
\mathrm{lkg} \text { (sourced from electrician) }\end{array}$ & 24 \\
\hline Bricks & $\begin{array}{l}\text { From chimneys that were carefully knocked } \\
\text { over, transported to yard and de-mortared. }\end{array}$ & $\begin{array}{l}720 \text { (Approximately } 900 \text { bricks per chimney, less } 20 \% \\
\text { breakage) } \\
\text { Selling price: } 50 \mathrm{c} \text { per brick }\end{array}$ & 720 \\
\hline Scrap steel & $\begin{array}{l}\text { Corrugated sheet from roof, and lead door } \\
\text { weights. Nothing suitable for re-use, however } \\
\text { can be stockpiled at yard until enough to take } \\
\text { to metal recyclers. }\end{array}$ & $\begin{array}{l}\text { Approximately } 0.6 \text { tonnes of steel salvaged in total. } \\
\text { Scrap price: } \$ 295 \text { per tonne }\end{array}$ & 177 \\
\hline Oregon Beams & $\begin{array}{l}\text { One } 4 \mathrm{~m} \text { long beam, plus approximately } 6 \mathrm{~m} \\
(150 * 50 \mathrm{~mm} \text { section) salvaged from roofing } \\
\text { structure. }\end{array}$ & $\begin{array}{l}\text { Selling prices: up to } \$ 30 / \mathrm{m} \text {, average } \$ 25 / \mathrm{m} \\
4 \mathrm{~m} @ \$ 25=\$ 100 \\
6 \mathrm{~m} @ \$ 4.4=\$ 26\end{array}$ & 126 \\
\hline Waste timber & $\begin{array}{l}\text { All timber from site that cannot be sold is cut } \\
\text { and sold as firewood, or burned at yard. }\end{array}$ & $\begin{array}{l}\text { Approximately five tonne of timber left at site that can } \\
\text { be sold as firewood, excluding sub-floor, of which } \\
\text { approximately } 50 \% \text { is returned to yard. (approx } 3 \\
\text { trailer-loads per tonne) } \\
\text { Selling price: } \$ 40 \text { per trailer-load. }\end{array}$ & 300 \\
\hline \multicolumn{3}{|l|}{ Total for Income } & 11,509 \\
\hline
\end{tabular}


APPENDIX 3: PLANT COSTS

\begin{tabular}{|c|c|c|c|}
\hline COST ITEMS & DESCRIPTION & COST REASONING & $\$$ \\
\hline Mechanical & $\begin{array}{l}\text { Twenty-three tonne excavator used to crunch } \\
\text { dwelling into transportable sized pieces. Full } \\
\text { day of use (day 4). }\end{array}$ & $\begin{array}{l}\text { Hired from supplier (including fuel only) } \\
\text { Price: } \$ 90 \text { per hour. } \\
\text { Hours: } 10 \text { (Incl. travel) }\end{array}$ & 900 \\
\hline Trucks & $\begin{array}{l}\text { The first truck used every day of work } \\
\text { (company owned) to transport salvaged } \\
\text { material to yard \& rubble on final day. } \\
\text { The second one is outsourced and used on } \\
\text { final day to transport rubble to landfill. }\end{array}$ & $\begin{array}{l}\text { 1st truck: operating costs mentioned below. } \\
\text { 2nd truck: } 9 \text { hours @ } \$ 60 / \mathrm{hr}\end{array}$ & 540 \\
\hline Maintenance \& Fuel & $\begin{array}{l}\text { The first truck (as described above). Running } \\
\text { costs include: Servicing (incl. Parts) \& Fuel. } \\
\text { The second truck (as described above) }\end{array}$ & $\begin{array}{l}\text { 1st truck: cost to company based on per } \mathrm{km} \text { rate, } \\
\text { incorporating running costs. } \\
\text { 2nd Truck: included in day-rate. } \\
\text { Servicing: } 2 \text { times per year @ } \$ 450=\$ 900 \\
200 \text { working days per year } \\
\$ 4.5 \text { per day*5 days }=\$ 22.5 \\
\text { Fuel: average } 180 \mathrm{kms} \text { per day @ } 0.32 \mathrm{c} \mathrm{km} \text {. } \\
\left(4^{*} 180\right)^{*} 0.32=\$ 230\end{array}$ & 253 \\
\hline Transportation & $\begin{array}{l}\text { Transportation of plant to site. Use of } \\
\text { company vehicles. }\end{array}$ & $\begin{array}{l}\text { Plant: no cost (included in day rate) } \\
\text { Company vehicle } \\
\text { three trips, average } 50 \mathrm{~km} \text { travelled. }\end{array}$ & 27 \\
\hline Financials & $\begin{array}{l}\text { Insurance, finance and depreciation costs of } \\
\text { plants to complete a project }\end{array}$ & $\begin{array}{l}\text { Truck: a total premium value of } \$ 2200 \text { is assumed for } \\
\text { a year. }\end{array}$ & 55 \\
\hline Total Plant Cost & & & 1,775 \\
\hline
\end{tabular}


APPENDIX 4: ENVIORNMENTAL COSTS

\begin{tabular}{|c|c|c|c|}
\hline COST ITEMS & DESCRIPTION & COST REASONING & $\$$ \\
\hline Waste Disposal & $\begin{array}{l}\text { Disposing of the miscellaneous rubbish from } \\
\text { site. Transport costs already allowed for, so } \\
\text { this is only the tipping fee calculation. }\end{array}$ & $\begin{array}{l}\text { Total of ten loads of rubbish removed in Day } 4 \text {. Four } \\
\text { go to yard to separate timber for firewood, six to } \\
\text { Drysdale tip. } \\
\text { Average truck load: } 7 \text { tonnes* } \$ 37.60 \text { /tonne }\end{array}$ & 1,578 \\
\hline Dust Protection & No dust on site. & & 0 \\
\hline Site Management & Not enough people on site to warrant. & & 0 \\
\hline Water Management & $\begin{array}{l}\text { Allow for waste minimisation measures to stop } \\
\text { rubbish being washed away, should it rain. }\end{array}$ & Relatively small allowance ( $1 \%$ of Total Project Cost) & 69 \\
\hline \multicolumn{3}{|c|}{ Total Environmental Cost } & 1,647 \\
\hline
\end{tabular}

\section{APPENDIX 5: ADMINSTRATIVE COSTS:}

\begin{tabular}{|c|c|c|c|}
\hline COST ITEMS & DESCRIPTION & COST REASONING & $\$$ \\
\hline Estimating & $\begin{array}{l}\text { Half a day minimum. Can be up to three or } \\
\text { more days depending on complexity of job. } \\
\text { Includes site inspection if necessary. }\end{array}$ & $\begin{array}{l}\text { Based on worth of estimator to company's operation. } \\
\text { Assume } 6 \text { hrs @ } \$ 50 \text { p/hr. }\end{array}$ & 300 \\
\hline Permits & Standard Demolition Permit & Standard constant & 350 \\
\hline $\begin{array}{l}\text { Equipment \& } \\
\text { Maintenance }\end{array}$ & $\begin{array}{l}\text { An allowance for the purchase of new } \\
\text { equipment (tools, etc.), and the maintenance } \\
\text { of that equipment. Medium level tool usage. }\end{array}$ & $\begin{array}{l}\text { Based on a percentage, relating to the amount of } \\
\text { usage required for the particular project. } \\
\text { A } 3 \% \text { addition to the total project cost calculated before } \\
\text { these percentages added }\end{array}$ & 208 \\
\hline Overheads & $\begin{array}{l}\text { Phone calls, accountant fees, etc, general } \\
\text { business operating costs. }\end{array}$ & $\begin{array}{l}\text { Based on the size of the company performing the } \\
\text { work, a } 5 \% \text { addition to the total project cost without } \\
\text { labour component }\end{array}$ & 200 \\
\hline \multicolumn{3}{|c|}{ Total Administrative Cost } & 1,058 \\
\hline
\end{tabular}

